\title{
ROLE OF FEMALE PARLIAMENTARIANS IN POLITICAL AND SOCIAL CHANGE IN PAKISTAN
}

\author{
Nawaz Ahmed \\ Lecturer \\ Department of Political Science \\ University of Turbat \\ Turbat - Pakistan \\ nawaz.ahmed@uot.edu.pk \\ Habiba Mushtaq \\ Lecturer \\ Government Girls Degree College \\ Turbat - Pakistan \\ habibamushtaq92@gmail.com \\ Jamil Ahmed \\ Lecturer \\ Department of Political Science \\ University of Turbat \\ Turbat - Pakistan \\ jamil.ahmed.uot.edu.pk
}

\begin{abstract}
This article attempts to elucidate the female parliamentarian's role in social and political change in Pakistan by looking at it through the lens of the country's historical progress. With an emphasis on historical evolution and current situation, the article also discusses social constraints that have made it difficult for women to engage in the political system in the past. Women's political engagement should be enhanced in the future, and an assessment of these concerns may produce some helpful ideas. In this study article, researchers have examined employing a qualitative research approach which is also called market research method that focuses on acquiring data through open-ended and conversational dialogue. These qualitative research approaches allow for in-depth and additional probing and questioning of respondents based on their responses, where the researchers also seek to understand their purpose and sentiments. The study also finds that Women's political empowerment across the country is limited by social and cultural standards, as well as by their economic




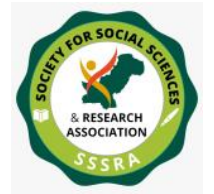

Pak. Journal of Int'L Affairs, Vol 4, Issue 3 (2021)

Role of Female Parliamentarians In ...

dependency on the male counterparts of their household. Women's engagement is also limited by low literacy rates and the segregation of men and women in social positions. There will be no meaningful impact on women's engagement in the public life particularly political life, until there is a progressive adjustment in societal standards, which should begin at the grassroots level and work its way up. For starters, women must be granted greater social and economic autonomy.
\end{abstract}

Keywords: Political Participation, Women Parliamentarians, Political Process, Representation

\title{
INTRODUCTION
}

The purpose of this article is to understand the role played by female parliamentarians in social and political transition in Pakistan by examining it through the lens of the country's historical development (Imran, and Shahzad, 2019). With an emphasis on historical advancement and current conditions, the essay also addresses social barriers that have made it difficult for women to participate in the political system in the past. Getting allowed to participate in politics is contingent on more than just being elected to the legislative assembly (Imran, and Shahzad, 2019). It also takes into consideration women's roles as voters and as members of political parties, as well as other aspects of participation in the political process, system, and structure. Women's political participation should be expanded in the future, and an examination of these issues may yield some constructive recommendations.

\section{Literature Review}

\section{Historical Development of the Representation of Women in the Political Structure}

According to Khan et al., (2020) Pakistani males and females differ in a variety of ways, as evidenced by the population ratio, school enrolment rates, literacy rates, and access to basic health care facilities, among other things. However, women's participation in politics has increased dramatically over the previous 16 years, according to the Pew Research Center. Women's political participation in legislatures has increased considerably in recent years, which is noteworthy in and of itself. A significant contribution to this shift in political participation has been made by Pakistan's legal obligations to the international community, including the Committee on the Universal Declaration of Human Rights (UDHR), Elimination of Discrimination against Women, and the International Covenant on Civil and Political Rights (ICCPR). Following the Fourth World Conference on Women in 1995, Pakistan began to feel the effects of these 


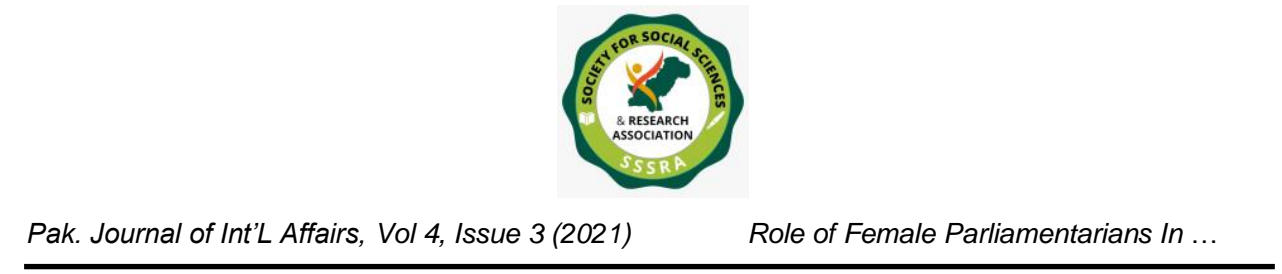

pledges and commitments. It is also important to note that the Pakistani Constitution of 1973 had a huge impact on the growth of women in Pakistani politics.

As Jabeen, (2021) mentioned, the EC Order of 2002, the Political Parties Order of 2002, and the Allocation of Reserved Seats for Women and Non-Muslims in the National Assembly and Provincial Assemblies Rules of 2002 have all contributed to the empowerment of women and the guarantee of their political participation in the political system. In Pakistan's current political framework, a presidential and a parliamentary component coexist side by side. Political systems have shifted as a result of adjustments in political structure that have occurred over the course of the last many decades. Historically, and across political systems, the proportion of female legislators in national and provincial legislatures has varied (Khan et al., 2020).

Jabeen, (2021) said from August 10, 1947 to October 24, 1954, women held two of the thirty seats in the first Pakistani legislative assembly; however, there was no president in place from 1947 to 1956. The governor general was in charge of the country's administration as its highest executive (Rubab et al., 2020). During this second legislature, which convened from May 2, 1955, until October 7, 1958, women were completely absent from the proceedings. There were a total of 80 seats available, with no seats reserved for women. Between 1956 and 1958, the political scene saw yet another transformation. Since the role of governor general was abolished, Iskander Mirza has served as the country's president. A period of military administration followed, which lasted for another 13 years and brought the country to a standstill (from 1958 to 1971).

According to the study of Jabeen, (2021) a second major revolution in political structure occurred in 1988 when the Zia regime came to an end; this time the representation of women in politics was altered significantly, as well. Female representation in the National Assembly has increased from 3 percent assigned quota in the first legislative assembly to 10 percent in 1988 (Jabeen, 2021). Women have been elected to 22 seats in the National Assembly (of which 21 were elected to reserved seats and 1 was elected directly) and 5 percent of seats in provincial legislatures since the first legislative assembly was established.

Khan et al., (2020) said the provision of women's reserved seats, on the other hand, was repealed from 1990 until 1997. Women were denied representation in the elected assemblies of 1990, 1993, and 1997, regardless of whether the assembly was at the provincial or national level (Jabeen, 2021). As a result, women's participation in the workforce was exceedingly low - barely 0.9 percent in 1990. (the number of directly elected women was 2 out of 217). As of 1993, women made up 1.8 percent of the 


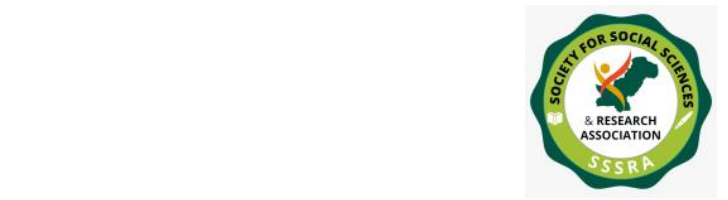

Role of Female Parliamentarians In ...

electorate (4 out of 217 were elected directly), while the percentage of women in elected legislatures increased somewhat to 2.8 percent for the national parliament in 1997. (the number of directly elected women was 6 out of 217).

Moreover Rubab et al., (2020) said, in 2000, the local government participation quota for women was raised to 33 percent for the first time since the country was placed under military administration. This quota applied to the levels of local government at the union council, district levels, and tehsil, Preparing for the 2002 election, the proportion of women in national and provincial legislatures was increased to 17 percent from the previous 16 percent (with 61 out of 342 members in the national assembly being women). Women's engagement in the political system increased significantly when a significant increase in the quota for women was implemented for the 2002 elections. As a result, more women than ever before ran for and won general elections seats in the Central Legislature of Pakistan. In the 2002 elections, a total of 188 women ran for general seats; 101 of these women were nominated by political parties, and 39 of these women were elected.

The female participation rate in this election was approximately one-third higher than it was in the previous election in 1997. During the 1997 election cycle, only 56 women ran for office, 39 of whom were nominated by political parties, and only seven were elected to office (Khan et al., 2020). The elections of 2008 and 2013 did, however, reveal some distinct differences in the tendencies that were seen. In the 2013 elections, women won 70 seats in the lower house of the national legislature, accounting for more than 20.5 percent of the total number of seats in the lower house.

Rubab et al., (2020) said, during the 2018 general elections, women were elected to 17 seats in the upper chamber, representing 17 percent of the total number of seats. The number of women who cast ballots in the 2013 elections was higher than the last election, which took place in 2008. Political parties nominated a total of 34 women to run for office in the general elections of 2008. In the most recent elections, political parties nominated 36 women to serve as presidential candidates. In the 2013 elections for the 272 National Assembly seats, 108 women ran for the positions. Compared to the 2008 elections, when there were a total of 76 female candidates, this is an obvious increase. The number of women running for political office in various political parties, such as the Pakistan Muslim League (Nawaz) and Mutahida Qaumi Movement, has increased significantly since the 2013 election, when compared to the previous elections in 2008. However, following the 2008 general elections, the proportion of women in other political parties such as the Pakistan People's Party (PPP) and the Pakistan Muslim League-Quaid-e-Azam (PML-Q) has fallen. 


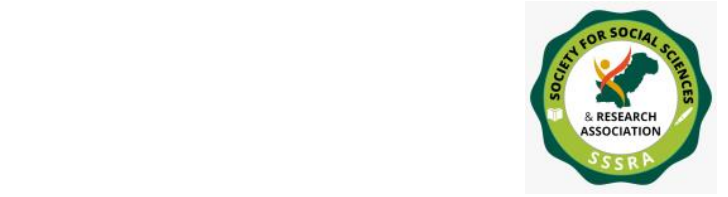

Pak. Journal of Int'L Affairs, Vol 4, Issue 3 (2021)

Role of Female Parliamentarians In ...

\section{Women's Political Participation: Current Trends}

Meanwhile, Mohsin, and Syed, (2021) stated that three critical questions can be used to assess the current condition of women's political engagement. These are: How many women received party tickets in the most recent election cycle? Is there a statistically significant difference between the number of women elected to general seats in provincial and national legislatures and the number of women elected to reserved seats in these legislatures? Despite the fact that women played an active role in the 13th National Assembly, according to the available researches, political parties failed to recognise this by nominating them for positions in the legislature. While the political parties nominated a total of 3.5 percent of female candidates, 96.5 percent of the candidates were male, according to the results. It appears that political parties have little faith in women, based on their low electoral participation, which is in stark contrast to the high level of political activity that women display.

It has been argued by Mohsin, and Syed, (2021) that additionally, in 2005 the United Nations Development Programme (UNDP) found that the proportion of women in political party decision-making positions has decreased. Political parties regard women as a resource that is mostly untapped. As a result, women are commonly utilised as symbols at public events and in political campaigns, which is unfortunate. Female-dominated political parties, on the other hand, serve primarily as representational bodies and have little influence on how decisions are made within the parties. Consequently, women's engagement in electoral politics has been hampered as a result of systemic inequalities inside political parties. In spite of this, the fact that there were more women running for seats in the National Assembly General Elections in 2013 than there were in 2008 represents a considerable advancement.

Consequently, Mushtaq, (2018) believed that this is largely owing to Pakistan's ratification of international treaties and human rights agreements, as well as its participation in international organisations. Thus, organisations such as the United Nations Development Program (UNDP), the Oxford Committee for Famine Relief (OXFAM) and others have collaborated with national and local organisations in order to encourage effective engagement of women in politics. UN Women is one of these organisations. There has been a mixed record in Pakistan when it comes to the development of women's political empowerment, particularly when it comes to women's positions in political parties. However, when it comes to exhibiting constructive female political participation, Pakistan has set the bar high for other Muslim countries to follow. Benazir Bhutto became the first female prime minister of a Muslim country when she was elected in 1988. 


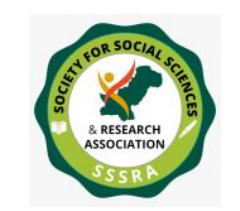

Role of Female Parliamentarians In ...

Pakistan's Fahmida Mirza made history as the first female speaker of a national assembly in the Muslim world. In addition, over 100 women were elected to both the upper and lower chambers of Pakistan's national legislative assembly in 2013, bringing the total number of women legislators in Pakistan to approximately 200.

Furthermore, following the country's 2008 elections, the PPP-led government appointed women to significant positions. Several women held prominent positions in the government, including ministers of social welfare, with Samina Khalid Ghurki acting as the ministry's director of special education, among others. Ashiq Firdous Awan, like Sherry Rehman, served as Minister of Health, and Hina Rabbani Khar, like Sherry Rehman, served as Minister of Foreign Affairs. Some of these female legislators went on to work in different ministries later on in their careers. Only two women are ministers in the current cabinet, which has a lower proportion of women in general. Rehman Ahmed Khan, Saira Afzal Tarar, Anusha Minister of Information and Technology, and State Minister for National Health Services, were also in attendance. Although they perform and make decisions as their male colleagues and conterparts, they are not as visible as they should be.

Rubab et al., (2020) have stated, the Election Commission of Pakistan (ECP) intended to collect information on voter turnout depending on gender during the 2013 parliamentary elections, but this was not the case. Instead of saying it another way, an analysis by the Free and Fair Election Network (FAFEN) found that "up to two-thirds of polling station presiding officers failed to fill out the specific sections of form correctly, raising concern that the ECP may not be able to provide accurate gender-segregated turnout." According to the EU Election Observation Mission (EU EOM), there was no sex-based counting carried out during the whole election process (Mushtaq, 2018). A preliminary FAFEN analysis of 3,070 polling stations in 92 National Assembly seats found that male voter turnout remained at 56.03 percent at male polling stations, while female voter turnout remained at 48.79 percent at female polling stations. Men were more likely than females to vote in this election, indicating that women were less involved in this election than men (Khan, and Naqvi, 2018). According to the EU EOM, factors such as lack of or inadequate toilet facilities at polling stations, and the absence of separate polling stations for men and women in areas where socio-cultural gender segregation is rigid, can all be considered as reasons for lower female voter turnout (2013). The number of women who cast ballots in the 2013 midterm elections could have been influenced by such factors.

\section{METHODOLOGY}




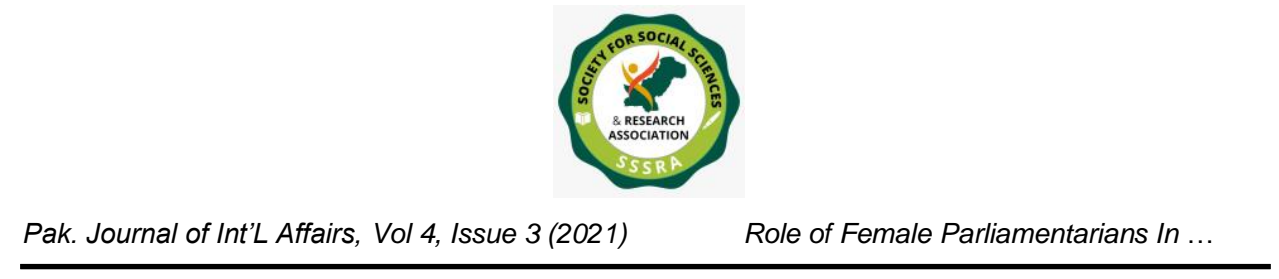

\section{Qualitative Research Method}

In this research paper researchers have considered using qualitative research method which is also called market research method that focuses on obtaining data through openended and conversational communication. These qualitative research methods allow for in-depth and further probing and questioning of respondents based on their responses, where the researchers also try to understand their motivation and feelings. Understanding a researcher's audience takes decisions can help to derive conclusions in market research of women's political participation in parliament.

\section{Data Collection}

To study whether women politicians were framed as objectifying candidates, to promote their perception as less competent in political matters, the researchers considered the qualitative research method in which 4 female respondents have been considered. The questions asked in the conversational interviews were semi-standardised in the sense that depending on the person asked, if she was a Member of Parliament, representing a political party or an NGO, the questions differed. The questions were open ended where the respondents had the chance to give her own personal opinion within the theme or question asked.

\section{Data Analysis}

Bukhman (2021) highlights how a major step towards the clarification and standardisation of qualitative methodologies of research began in the 1980s and was primarily influenced by qualitative techniques of research (Kazdin, 2021). This type of data analysis is commonly used in qualitative research and is referred to as thematic analysis (Springer, et al., 2021). As described by Marczyk et al. (2021), Thematic Analysis is an interpretative process in which the investigator carefully evaluates data for patterns that might be used to describe the event being researched. 


\section{Interview Analysis}

\section{RESULTS}

The questions that were asked, as well as the responses that were provided, are listed in the following section. In the study's nine random participants, four of whom were female, consumers made up the vast majority of the group. At the moment, it's the one that's getting the most attention when it comes to coding practices.

\begin{tabular}{|c|c|c|c|c|c|}
\hline \multicolumn{6}{|c|}{ Question and Participants Responses } \\
\hline Questions & Participant 1 & Participant 2 & Participant 3 & Participant 4 & Theme \\
\hline Questions 1 & $\begin{array}{l}\text { equality will be } \\
\text { measured }\end{array}$ & Can't be same & $\begin{array}{l}\text { It is important in } \\
\text { every field }\end{array}$ & $\begin{array}{l}\text { quotas for women } \\
\text { will not achieve the } \\
\text { desired outcomes }\end{array}$ & $\begin{array}{l}\text { Theme l: Gender } \\
\text { equality }\end{array}$ \\
\hline Questions 2 & $\begin{array}{l}\text { Participants are not } \\
\text { equal }\end{array}$ & It has to be same & $\begin{array}{l}\text { Women were not } \\
\text { allowed to vote } \\
\text { long time back }\end{array}$ & $\begin{array}{l}\text { Male participants } \\
\text { are dominant }\end{array}$ & \\
\hline Questions 3 & $\begin{array}{l}\text { Third worst country } \\
\text { for gender equality }\end{array}$ & $\begin{array}{l}\text { No rights as male } \\
\text { have }\end{array}$ & No equal possibility & No equal possibility & \\
\hline Questions 4 & $\begin{array}{l}\text { More challenges } \\
\text { women faces }\end{array}$ & $\begin{array}{l}\text { More challenges } \\
\text { women faces }\end{array}$ & $\begin{array}{l}\text { More challenges } \\
\text { women faces }\end{array}$ & $\begin{array}{l}\text { More challenges } \\
\text { women faces }\end{array}$ & $\begin{array}{l}\text { Theme 2: Women } \\
\text { faces more }\end{array}$ \\
\hline Questions 5 & Conferences & Women speakers & $\begin{array}{l}\text { Participation of } \\
\text { women in every } \\
\text { function }\end{array}$ & $\begin{array}{l}\text { Presentation and } \\
\text { good behavior }\end{array}$ & $\begin{array}{l}\text { challenges to be a } \\
\text { part of parliament }\end{array}$ \\
\hline
\end{tabular}

\section{Creation of Themes:}

The themes provided in the table above were obtained from the responses of the participants, as well as the keywords they chose as codes to categorise their responses. The idea is to demonstrate how the themes associated with the questions developed throughout time. A number of themes arose as a result of the keyword study, which are depicted in the accompanying figure. 

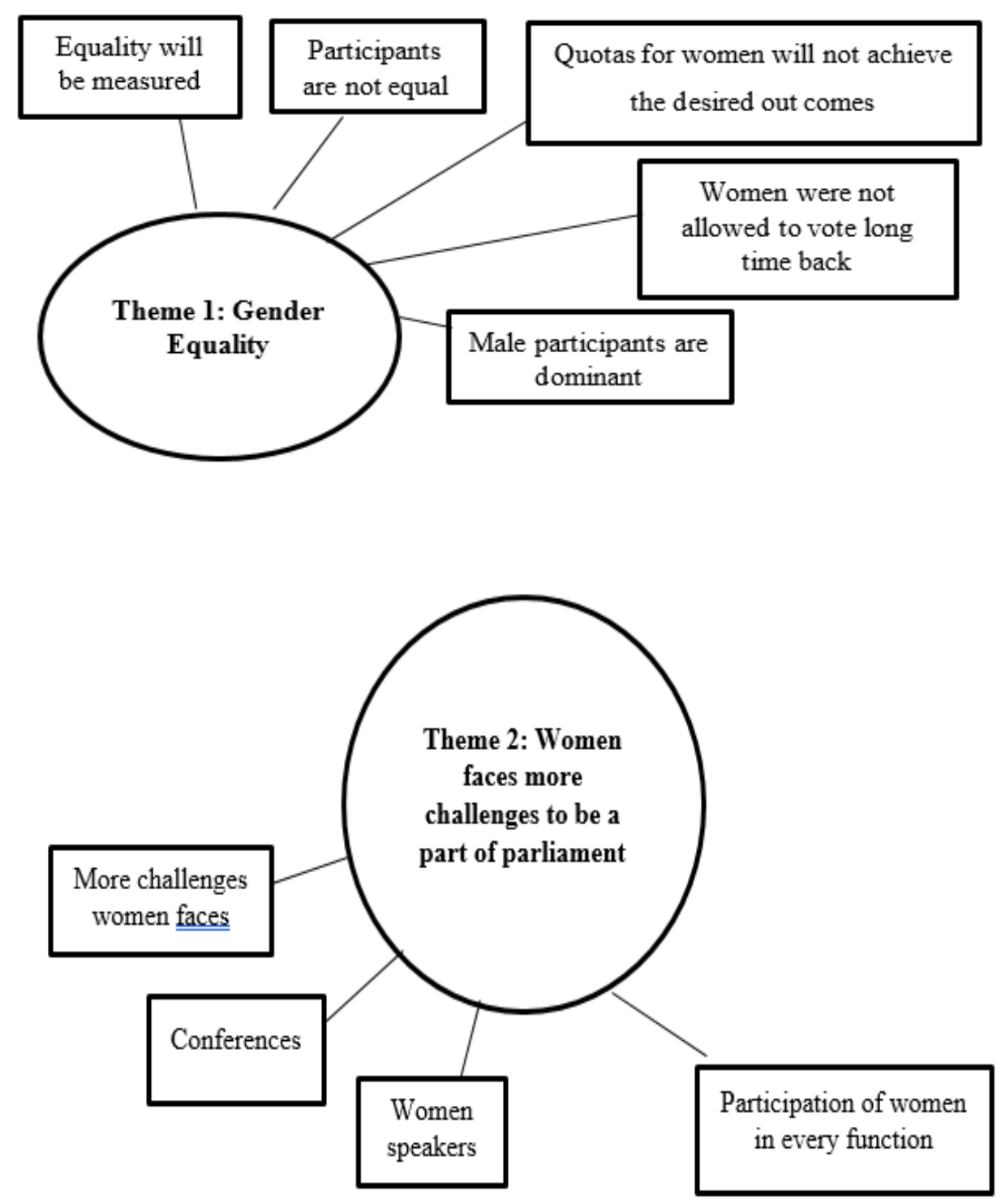

\section{Results from Interview Question}

R1: Is it important with gender balanced representation?

According to (Interviewee 1) "Yes gender balanced representation is most important, in that way every gender know other gender's rights and its respect" While (Interviewee 2) 


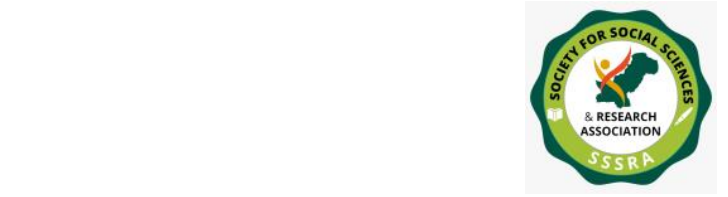

Role of Female Parliamentarians In ...

replied "The balance in gender representation cannot be remain same, men always has to be one step forward as compare to women". (Interviewee 3 and 4) mentioned that "yes it is important because in this world women are not behind men they are in equal position in every field today" while others said the same that "quotas for women will not achieve the desired outcomes". According to her "Women's population, voter registration, and turnout must all be taken into consideration in order to fully appreciate the problems that women's empowerment has faced in the recent past".

R2: Would you consider gender equality issues and women's political participation high priority questions?

The findings from this (Interviewee 1) were "yes there are lots of issues a women faces as an equal rights but by the time, people are having awareness about it and also the participation rate in parliament has also been upgraded as compared to previous rates. But according to (Interviewee 2) "The participation rate is upgraded but the gender equality in parliament or any political party is still not as same as it supposed to be" While (Interviewee 3) said "Women account for over half of Pakistan's population, and nearly 37.6 million women were registered to vote in the 2013 general election, compared with nearly 48.6 million registered male voters. This exposes a gap of approximately 11 million female voters who have not registered to vote " that means the rights are not the same. According to (Interviewee 4) "there is a statistically significant gender discrepancy let suppose in voter registration. Female voter registration is lowest in the Federally Administered Tribal Areas (FATA), Balochistan, and Khyber Pakhtunkhwa (KP), whereas Islamabad and Sindh have lower gender disparities than other regions of the country".

R3: Do you consider women in Pakistan to have equal possibilities to get elected into the national Parliament?

(Interviewee 1) said "Pakistan is the third worst country in the world for gender equality, ranked $151^{\text {st }}$ out of 153 countries studied, there isn't any equal possibility to get elected into national parliament". (Interviewee 2) responded that Women always have a tough time during elections in the national parliament. While (Interviewee 3) said, "There is not any equality until gender is capable. The capability and hard work will send a person to his place whether it is parliament or any other place". (Interviewee 4) said "women do not have equal possibility to get elected into the national parliament".

R4: Do you think that women face more challenges in politics as compared to men?






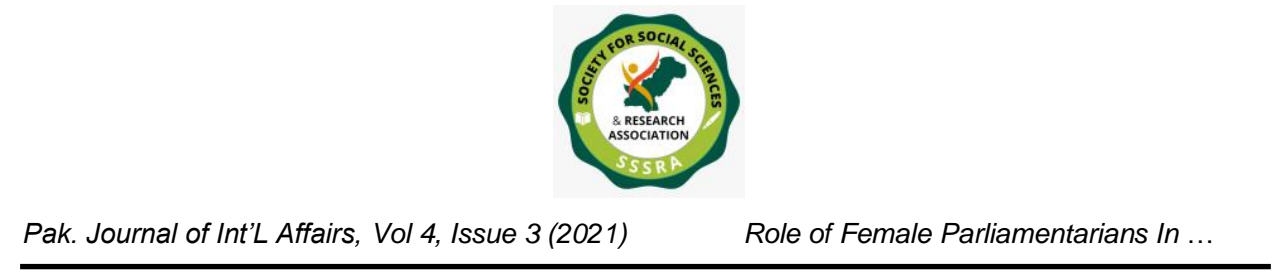

According to the findings from this interview question, all of the interviewers replied that there are always more challenges for women as compared to men. Poverty and gender inequality are inextricably linked because deeply rooted discriminatory customary practises reinforce the poor social standing of women and other marginalised groups. Since the early 1970s, women's rights organisations have been working to eliminate roadblocks that stand in the way of resolving gender inequality in the country and bringing about positive change.

R5: What are some strategies that a government or organization apply for increasing women's representation?

(Interviewee 1) said political parties should spread awareness conferences so women start willingness to participate in politics and political parties. (Interviewee 2 and 3) replied that political parties should make a clean and fair environment that represents a good message to other female students so they can further take part in politics and political parties. While (Interviewee 4) said, "In national assembly, political programs and any political function women should be equivalent and represented so it sends a good impact to other women.

\section{Demographics of interview Participants}

\section{Please state your job title.}

Participant 1: I am a political worker

Participant 2: I work in an NGO that is run by political party

Participant 3: I am a political worker

Participant 4: Political worker.

2. Please state your age range: $22-25 ; \mathbf{2 6 - 3 0 ; 3 1 - 3 7}$

Participant 1:28

Participant 2: 35

Participant 3: 30

Participant 4: 32

\section{Summary}

After the survey, interviews and study of the previous available data, it is concluded that most of the people do care for the environment, however the lack of knowledge has been highlighted which is women's responsibility to provide the awareness. People from different backgrounds highlighted some main issues but the end point that researchers concluded from the results is that women in politics and women who belong to any

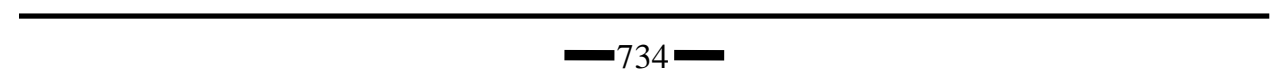




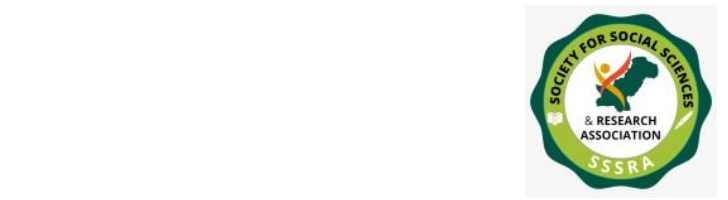

Role of Female Parliamentarians In ...

political party, have to face several challenges and the political and social environment always focuses on men, so it influences their positions and intentions towards power.

\section{DISCUSSION}

Female representation in legislative bodies is obviously lacking in Pakistan, according to the World Bank, because of the general perception that "a woman's place is still at home and political activity is for men," as stated by the World Bank (Mushtaq, 2018). Women are generally discouraged from entering public life and political responsibilities, with the exception of those "who come from the families having strong political background," who are given special consideration. Reservations of seats for females, on the other hand, are in direct conflict with women's empowerment concept and dedication to equal opportunity.

Women's political engagement in the political structure cannot rise with minimum economic empowerment. The consequence is that this level of female representation in the political system falls short of what would be considered authentically indigenous. Many individuals believe that women's primary role and task is to care for their families, and should limit themselves within the private sphere of life. They believe that women should refrain from participating in political activities (Zakar et al, 2018). Women's political participation is hindered by a variety of social, cultural, and economic concerns. For example, a research conducted in the Pashtun parts of KP province in Pakistan discovered that women in those areas face challenges such as gender segregation, low literacy rates, and lack of knowledge about their political rights, among other things. Furthermore, in that region, societal conventions place women in an inferior position to their male counterparts. Thus, depriving females from their legal and political rights.

\section{FINDINGS}

Political arena in South Asia is primarily centred on money and power resources, as well as political networking. All of which are intricately intertwined. Women often have less opportunity to join a powerful political network and have less access to economic resources unless they are born into a politically active family (Imran, and Shahzad, 2019). There are a variety of factors that prevent women from participating in politics, including constraints on economic empowerment, lack of knowledge and as well as lack of political networks in their communities.

Female elected officials in Pakistan currently account for a higher proportion of the total than they did during the previous election cycles, thanks to the implementation of a quota system. Women, on the other hand, constitute a larger proportion of those running for 


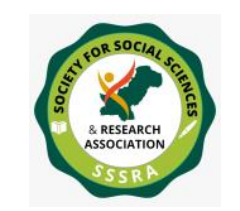

Role of Female Parliamentarians In ...

general election seats in legislative bodies. Additionally, women are exercising their right to vote in higher numbers than they have in the previous decades (Imran, and Shahzad, 2019). It is because of their active participation in Pakistan's 13th and 14th National Assembly's sessions that the political parties had nominated them for this position. Additionally, there were more women standing for offices in the 2013 elections than there were in the last elections, which were held in 2018. However, despite this, women continue to lack the political influence that current data and trends in the political system and structure would have believed (Zakar et al, 2018). With the quota system in place, there has been a dramatic increase in the number of women serving in legislative bodies in the country.

It is appropriate to express gratitude for the quota system for women who have entered politics, given they are not elected by the general public but instead are appointed to their positions within political parties by the party administration. While avoiding direct election may make inclusion in the political system more expedient, it also means that they are not real representators of Pakistan's socio-cultural class, which is predominantly made of Pakistani women (Zakar et al, 2018). This is especially true given the fact that the majority of women who have served in legislatures come from well-known political families (Tehmina Daultana, Benazir Bhutto, Hina Rabbani Khar, Fahmida Mirza, Maryam Nawaz, Syeda Abdia Hussain, etc.). The number of women nominated by their political parties to run for general seats remains fewer than the number of men, demonstrating that women's electoral potential continues to be undervalued. Women's wings within political parties also play a less effective role in policymaking, preferring to serve representative functions rather than executive functions (Mushtaq, 2018). The fact that political parties have done so little to empower women is once again demonstrated.

\section{CONCLUSION}

Women's political empowerment is hampered by social and cultural standards, as well as their economic dependency on the male counterparts. Women's participation is also hindered by low literacy rates and the segregation of men and women in social roles. There will be no significant impact on women's participation until there is a progressive adjustment in societal standards, which should begin at the grassroots level and work its way up. For starters, women must be given greater social and economic autonomy. Once this is accomplished, women will be able to assume more progressive and powerful roles in the political system as a result of their achievements. A bottom-up strategy to women's political empowerment, such as quotas or other legal measures needs to be strengthened. Socio-cultural discrimination, on the other hand, continues to be the normative set of practises inside political parties. Examples of these attitudes and behaviours include the 
allocation of roles and responsibilities, as well as the nomination of political parties. For women to be really empowered and have a voice in the political system, changes must be made at the local level and in society's institutions (particularly at the household and business level), as well as public awareness-raising efforts, among other things. 


\section{REFERENCE}

Imran, F. and Shahzad, A., 2019. Political Empowerment of Women in Pakistan; Performance of Female Parliamentarians in Punjab Assembly (Case Study of Lahore District: 2002-2007). Journal of Political Studies, 26(1).

Jabeen, M., 2021. Political Representation of Women in Parliament of Pakistan after Restoration and Increase in Gender Quotas (2002 to 2018). Pakistan Journal of Social Sciences (PJSS), 41(1), pp.163-174.

Khan, A. and Naqvi, S., 2018. Women in Politics: Gaining Ground for Progressive Outcomes in Pakistan. IDS. Bilal, M., Rehman, A.U. and Ahmad, A., 2018. Political reforms and women political participation in Khyber Pakhtunkhwa. Liberal Arts and Social Sciences International Journal (LASSIJ), 2(2), pp.67-79.

Khan, A., Yousuf, Z. and Naqvi, S., 2020. Women Politicians Navigating the 'Hostile Environment' in Pakistan. IDS Bulletin, 51(2).

Mohsin, M. and Syed, J., 2021. Female embodiment and patriarchal bargains: a contextspecific perspective on female politicians in Pakistan. Third World Quarterly, pp.1-19.

Mushtaq, M., WOMEN IN PARLIAMENT: INVESTIGATING THE ROLE OF WOMEN PARLIAMENTARIANS IN PAKISTAN.

Rubab, M., Mustafa, D.G. and Nawaz, A., 2020. Conundrum of Women Political Participation in Pakistan: Impediments and Opportunities. Pakistan Social Sciences Review, 4(2), pp.135-149.

Zakar, R., Zakar, M.Z. and Hamid, N., 2018. Gender mainstreaming in politics: Perspective of female politicians from Pakistan. Asian Journal of Women's Studies, 24(2), pp.224-245. 


\section{APPENDICS}

\section{Interview Questions}

Q1: Is it important with gender balanced representation?

Q2: Would you consider gender equality issues and women's political participation high priority questions?

Q3: Do you consider women in Pakistan have equal possibilities to get elected into the national Parliament?

Q4: What do you think that women faces more challenges in politics as compare to the men?

Q5: What actors have responsibility for increasing women's representation (NGO, Party, politicians, women's clubs?) 